\title{
Effect Processing Lamtoro Leaf (Leucaena leucocephala) As feed on Rex Rabbit Carcass
}

\author{
B Hardiansyah, M Tafsin, A H Daulay, T H Wahyuni, N Ginting \\ Animal Production Program, Faculty of Agriculture, Universitas \\ Sumatera Utara, Medan 20155 \\ E-mail: nurzainahginting@gmail.com
}

\begin{abstract}
This study aims to determine the best treatment of leaf lamtoro so it has not negative impact on the rabbit. Research conducted at the Laboratory of Animal Biology of Animal Husbandry Department on Faculty of Agriculture, University of Sumatera Utara starting from August -October 2016. The design used in this study is completely randomized design (CRD) with 4 treatments and 5 replication. The treatments were utilization of lamtoro leaf treated by drying the sun $(\mathrm{P} 0)$, oven $\left(70^{\circ} \mathrm{C} ; 12\right.$ hours) $(\mathrm{P} 1)$, steaming $\left(70^{\circ} \mathrm{C} ; 15\right.$ minutes + sun drying) (P2) and soaking (12 hours + sun drying) (P3). The parameters studied were slaughter weight, carcass weight, and carcass percentage.

The results showed that average slaughter weight (g/head) on treatment P0, P1, P2, P3 were 1562.20, 1576.60, 1413.20, and 1634.00; Carcass weight $(\mathrm{g} / \mathrm{head})$ were $780.60,804.60,693.40$, and 815.60; Carcass percentage $(\%)$ were $50.17,51.00,48.98,50.16$ respectively. Stastical analysis showed that treatment lamtoro in a pellet ration had no significantly effect $(\mathrm{P}>0,05)$ on slaughter weight, and carcass percentage, but the had different effect $(\mathrm{P}<0.05)$ on the weight of carcass. The Conclusion of this study is processing lamtoro leaf soaking 12 hours + sun drying, oven $70^{\circ} \mathrm{C} ; 12$ hours, drying the sun aplicable on rabbit diet.
\end{abstract}

\section{Introduction}

Rabbit is one of the commodities of meat-producing livestock that has great potential to be developed because it has the properties and its ability to grow and multiply rapidly.

A rabbit produces meat $50-60 \%$ of the weight of his life. Rabbit meat contains much lower fat and cholesterol compared to chicken, beef, lamb, and pork, but the protein content is higher [1].

In livestock farming cost of feed reaches $60-70 \%$ of total production cost. To reduce the cost of feed it is necessary to find a source of raw materials that are cheaper, easy to obtain, good nutrition, but not compete with human needs. One effort to reduce the cost of feed is to utilize leaf lamtoro which can be used as pellet ration for rabbits.

Lamtoro is generally grown as a hedge plant and a protective crop for commercial crops. The characteristics of the lamtoro plant, among others, have a height of up to 20 meters, a double-pinnate compound leaf with a fin number of 3-10 pairs (Garcia et al., 1996).

According to Hartadi et al., (2005) lamtoro plants are known to contain a very good protein used as animal feed. The nutrient content of lamtoro is crude protein (PK) $23.7 \%$, crude fiber (SK) $18 \%$ and crude fat (LK) $5.8 \%$ [2]. 
Lamtoro including forage with high nutritional value but its use as animal feed should be limited. Lamtoro contains anti-nutritional substances, namely non-protein amino acids called mimosin, which can cause poisoning or health problems if consumed in large quantities and continuously for long periods of time [3].

Efforts in decreasing mimosine in lamtoro leaf can be done with the aid of vapor pressure, heating (drying or forging), soaking, adding sulfate salts, spraying with alkali, adding mimosine analog compounds, washing and genetic engineering to obtain new varieties of low mimosine [4].

\section{Materials and Methods}

\subsection{Place and time of research}

This research was conducted at Livestock Biology Laboratory of Animal Husbandry Faculty of Agriculture University of North Sumatra Jl. A Sofyan No. 3. This study lasts for 8 weeks starting from August to October 2016.

\subsection{Materials and Research Tools}

The material used is 20 male rabbits rex rabbits, the ingredients of ration comprising corn flour, fine bran, fish meal, coconut meal, soybean meal, leucaena leucocephala flour, top mix, drinking water, rodalon as disinfectant, vitamins and supplements.

The tool used is $\mathrm{p} \mathrm{x} 1 \times \mathrm{t}$ that is $50 \mathrm{~cm}$, size 20 pellet, pellet printing machine, grinder machine, feeding and drinking each 20 units, tsermometer, plastic sheeting as base for pellet mix, shalter scale $5 \mathrm{Kg}$ capacity, , hygiene kennels

\subsection{Research methods}

The research method used was complete randomized design (RAL) with 4 treatments and 5 replications so that 20 units of experiments were obtained.

The treatment under study is as follows:

P0: Leaf lamtoro flour with sun drying.

P1: Leaf lamtoro flour with heating using oven (700; 12 hours).

P2: Lamtoro leaf flour with moist heating (700C; $15 \mathrm{~min}+$ sun drying).

P3: Lamtoro leaf powder with water immersion (12 hours + sun drying).

The mathematical model of RAL is as follows:

$\mathbf{Y i j}=\mu+\sigma \mathbf{i}+\mathbf{\varepsilon i j}$

Information :

Yij $=$

the observed value of the jth experimental unit receiving the $i$ th treatment

$\mu \quad=$ middle value

бi $\quad=$ the effect of the $i$-th treatment

$\boldsymbol{\varepsilon}_{\mathrm{ij}}=$ an experimental error on the jth threshold unit in the $\mathrm{i}$-th position

Observed Variables

1. Cutting Weight (g / tail)

Cut weight is obtained by weighing the final weights after dipuasakan 6-10 hours.

2. Carcass weights ( $\mathrm{g} /$ tail) 
The weight of carcass is obtained from the weighing of the meat with the rabbit that has been separated from the head to the base of the neck and from the feet to the ankle, the contents of the abdominal cavity, blood, tail and skin.

\section{Percentage of Carcass (\%)}

Percentage of carcass that is carcass weight is divided with $100 \%$ cutting weight.

$$
\text { Percentage of Carcass }(\%)=\frac{\text { Carcass weights }}{\text { Cutting Weight }} \times 100 \%
$$

\section{Results and discussion}

\subsection{Slaughter Weight}

\begin{tabular}{|c|c|c|c|c|c|c|}
\hline \multirow[t]{2}{*}{ Treatment } & \multicolumn{5}{|c|}{ Deuteronomy } & \multirow{2}{*}{ Average $^{\text {tn }} \pm \mathrm{SD}$} \\
\hline & 1 & 2 & 3 & 4 & 5 & \\
\hline $\mathrm{P}_{0}$ & 1710 & 1580 & 1215 & 1601 & 1705 & $1562,20 \pm 202,86$ \\
\hline $\mathrm{P}_{1}$ & 1470 & 1613 & 1670 & 1520 & 1610 & $1576,60 \pm 80,20$ \\
\hline $\mathrm{P}_{2}$ & 1475 & 1250 & 1709 & 1435 & 1197 & $1413,20 \pm 203,20$ \\
\hline $\mathrm{P}_{3}$ & 1470 & 1695 & 1665 & 1920 & 1420 & $1634,00 \pm 199,48$ \\
\hline
\end{tabular}

Table 1. Mean weight of male rex rabbits during the study (g/head)

Info: $\mathrm{tn}=$ no real difference

From Table 1 it can be seen that the diversity analysis showed that the effect of lamtoro leaf powder processing in the ration gave no significant effect $(\mathrm{P}>0,05)$ on the male rex rabbit's weights.

This is in line with the consumption of rations that also have no significant effect. As we know that the cut weight is closely related to the consumption of rations, the food substances that enter the body will also be higher so that the growth of livestock will be better which will ultimately increase the weight of the pieces produced

In a study conducted by Suradiet et al. (2007) on the appearance of rabbits given ration containing lamtoro leaf and its effect on meat production with sun drying treatment on lamtoro leaf with $20 \%$ use of lamtoro leaf flour in rasum can decrease consumption of ration and cut weight [5].

In research conducted by Suradi et al., (2007) yielded cut weights that amounted to 1697.14 g. The difference of cut weights produced in the research conducted, it is suspected because of differences in treatment and the results of different feed consumption resulting in different cut weights produced [5].

\subsection{Carcass weights}

Table 2. Meaning of male rex rabbit carcass weight during the study (g/head)

\begin{tabular}{lllllll}
\hline \multirow{2}{*}{ Treatment } & \multicolumn{3}{l}{ Deuteronomy } & & \multicolumn{2}{c}{ Average \pm SD } \\
\cline { 2 - 6 } & 1 & 2 & 3 & 4 & 5 & \\
\hline $\mathrm{P}_{0}$ & 845 & 783 & 653 & 792 & 830 & $780,60^{\mathrm{ab}} \pm 75,84$ \\
$\mathrm{P}_{1}$ & 742 & 834 & 856 & 751 & 840 & $804,60^{\mathrm{a}} \pm 53,74$
\end{tabular}




$\begin{array}{lllllll}\mathrm{P}_{2} & 770 & 595 & 839 & 686 & 577 & 693,40^{\mathrm{b}} \pm 112,19 \\ \mathrm{P}_{3} & 773 & 831 & 797 & 915 & 762 & 815,60^{\mathrm{a}} \pm 61,54\end{array}$

Info: Different letter notation in the mean column shows significantly different $(\mathrm{P}<0.05)$

From Table 2 it can be seen that the diversity analysis showed that the effect of lamtoro leaf flour significantly affected $(\mathrm{P}<0,05)$ on carcass weight.

This is due to the treatment of P2 (humid heating, for 15 minutes + sun drying) obtained the lowest body weight of $118.8 \pm 37.70 \mathrm{~g} /$ head / day resulting in a low average carcass weight of $693.40 \pm 112.19 \mathrm{~g} /$ ekor, low body weight on P2 is caused by low ration consumption resulting in low protein consumption as it is known that protein has a great influence on the growth of tendon and also resulted in the percentage of meat will also decrease. This is in accordance with the statement Nataamidjaya ,. et al (1995) That carcass production is closely related to body weight, whereas body weight gain is influenced by the quality of rations and the amount of rations consumed by livestock [6].

\subsection{Percentage of Carcass}

Table 3. Mean percentage of rabbit rabbit carcass carcass during study (\%)

\begin{tabular}{lllllll}
\hline \multirow{2}{*}{ Treatment } & \multicolumn{5}{l}{ Deuteronomy } & \multirow{2}{*}{ Average $^{\text {tn }} \pm \mathrm{SD}$} \\
\cline { 2 - 6 } & 1 & 2 & 3 & 4 & 5 & \\
\hline $\mathrm{P}_{0}$ & 49,42 & 49,56 & 53,74 & 49,47 & 48,68 & $50,17 \pm 2,02$ \\
$\mathrm{P}_{1}$ & 50,48 & 51,70 & 51,26 & 49,41 & 52,17 & $51,00 \pm 1,09$ \\
$\mathrm{P}_{2}$ & 52,20 & 47,60 & 49,09 & 47,80 & 48,20 & $48,98 \pm 1,89$ \\
$\mathrm{P}_{3}$ & 52,59 & 49,03 & 47,87 & 47,66 & 53,66 & $50,16 \pm 2,78$ \\
\hline
\end{tabular}

Info: $\operatorname{tn}=$ no real difference 
From Table 3 it can be seen that the diversity analysis showed that the effect of lamtoro leaf powder had no significant effect $(\mathrm{P}>0,05)$ on the percentage of carcass. This is assumed because in each treatment has different effect is not significant on the weight of cut and the percentage of carcass, because cutting weight can affect the percentage of carcass produced by a cattle because the proportion of body parts that produce meat will increase in harmony with the body weight. In a study conducted by Suradi et al. (2007) on the appearance of rabbits given rations containing sun-dried lamtoro leaves with $20 \%$ use and their effect on meat production can decrease the percentage of rabbit carcasses [5].

\section{Conclusions}

Leucaena leucocephala (leucaena leucocephala) does not affect the cutting weight, and the percentage of carcass, but can affect carcass weight. Weight rabbit carcass on treatment water immersion (12 hours + sun drying), oven heating $\left(70^{\circ} \mathrm{C}\right.$ for 12 hours), and sun drying has higher carcass weight than moisture heating $\left(70^{\circ} \mathrm{C}\right.$ for 15 minutes + sunlight drying $)$.

\section{References :}

[1] Masanto, R and A. Agus. 2010. Breed Rabbit Cut. The Swadaya spreader. Jakarta

[2] Hartadi, H., S. Reksohadiprojo, and A.D. Tillman. Feed Composition Table for Indonesia. Gadjah Mada University Press. Yogyakarta

[3] Hayanto, B. and A. Djajanegara. 1993. Fulfilling the Requirement of Small ruminants. Eleven March Univesity Press. Page 192-194

[4] Yosef, E. and D. Ben-Ghedalia. 2000. Changes in the alkalinelabile phenolic compounds of wheat straw cell walls as aff ected by $\mathrm{SO} 2$ treatment and passage through the gastro-intestine of sheep. J. Anim. Feed Sci. And Technol

[5] Suradi, K,. Yurmiaty, H,. and Rusmana, D. 2007. Appearance of Rabbits Which Have Rations Containing Leaves Lamtoro (Laucaena Leucocephala) And Its Effects On Meat Production. Faculty of Animal Husbandry of Padjadjaran University.Bandung

[6] Garcia, G.W.. T.U. Fergusson, F.A.Neckles dan K.A.E Archibald. 1996. The Nutritive Value and Forage Productivity of Leucaena Leucocephala. Anim Feed Sci Technol 